\title{
プライオリティシーリングによるオブジェクト指向 トランザクション処理*
}

\author{
浅井 研一†・小村 裕樹
}

\section{Object-Oriented Transaction Processing by Priority Ceiling*}

\author{
Ken-ichi ASAI ${ }^{\dagger}$, Hiroki KomUra ${ }^{\ddagger}$, Tomoko BABA ${ }^{\S}$ and Motoyasu NAGATA ${ }^{\llbracket}$
}

\begin{abstract}
The object-oriented transaction processing characterized by recursive invocation of method for object is realized by concurrency control which satisfies object-oriented serializability. As the conventional semantic concurrency control is executed by switching subtransactions, the transaction which has arrived subsequently can be partly executed by suspending the precedent transaction which has not been completed, as far as the object-oriented serializability is guaranteed. Despite of allowance of partial execution for the subsequent transaction, the semantic concurrency control faces the left off problem about precedent transactions, which means that the precedent transactions cannot be executed for a long time. This paper presents an object-oriented transaction processing by introducing priority ceiling to resolve the left off problem. Furthermore, to evaluate performance of our proposed method detailed experiments were carried out from various viewpoints. Especially, from experimental results about execution time of transaction, left-off transactions, execution time of transaction, suspended time and waiting time of subtransactions, we obtain detailed consideration of the performance evaluation and show effectiveness of our proposed object-oriented transaction processing by the priority-ceiling.
\end{abstract}

\section{1.はじめに}

オブジェクト指向トランザクションは, オブジェクト に対するメソッドの再帰的な起動を特徴とするため, オ ブジェクトとそれをアクセスするメソッドの一対からな るノードから構成される木構造となることが知られてい る.このような木構造のトランザクションを並行処理制 御するため, オブジェクト指向直列可能性なる概念 $[1]$

* 原稿受付 2005 年 12 月 1 日

$\dagger$ (株) NTTデータ 決済ソリューション事業本部 Payment Solutions Sector, NTT Data Corporation; Mita 3-9-11, Minato-ku, Tokyo 108-0073, JAPAN

‡（株）日立製作所 金融システム事業部 Financial Information Systems Division, Hitachi, Ltd; 890 Kashimada, Saiwai, Kawasaki, Kanagawa 212-8567, JAPAN

$\S$ (株) 日立製作所ソフトウェア事業部 Software Division, Hitachi, Ltd; Totsuka-cho 5030, Totsuka-ku, Yokohama-shi, Kanagawa 244-8555, JAPAN

『大阪教育大学 情報科学専攻 Department of Information Science; Osaka Kyoiku University, Asahigaoka 4-698-1, Kashiwara-shi, Osaka 582-8582, JAPAN

Key Words: object, transaction processing, priority-ceiling, performance evaluation.
に従うロック方式が提案されている.このロック方式に よるトランザクション処理は, オブジェクトをアクセス するサブトランザクションを切り替えながら実行される ことから, オブジェクト指向直列可能性を満たす限り, 先着のトランザクションに後着のトランザクションを割 り込ませて実行することが可能である。このトランザク ション処理は, 同一のオブジェクトを同時にアクセスす る二つのメソッドの組合せに対して，衝突または互換を 表す意味情報を参照して扢こなわれるため, 意味的並行 処理制御とよばれている。

まず，論文の背景および動機について述べる. Muth らが提案した意味的並行処理制御 [2] の方法に従って木 構造のオブジェクト指向トランザクションを並行処理す るとき, 先着のトランザクションの実行完了に先んじて 後着のトランザクションの部分的な実行を許すことから， 先着のトランザクションが長時間にわたり実行完了され ない状態のままに放置される状況が起こりうる。この ような先着トランザクションの積み残し現象の克服は, オブジェクト指向トランザクション処理の未解決問題と して残っていた. 本論文は，この積み残し問題の解決を 目的として，プライオリティシーリングを導入したロッ 
ク方式のオブジェクト指向トランザクション処理を提案 する.

プライオリティシーリングのタスクスケジューリング への適用は，オペレーティングシステムにおけるプロセ スの優先度逆転現象を解決するために, Shaらによる 提案 [3] が嗃矢である. 彼らは，セマフォのプライオリ ティシーリングをセマフォを使用する複数プロセス内の 最高のプロセス優先度として定義した. Ullusoyら [4] は [3] の定義を拡張して, トランザクション処理における データ項目のプライオリティシーリングは, 対象となる データ項目をアクセスする複数のトランザクションに付 加された優先度の中で最高の優先度と定義した。なお, Ullusoy らの考察対象は, 階層的なオブジェクト指向卜 ランザクションでなく, フラットなトランザクションで ある。

我々は, メソッドの再帰的な起動を特徵とする階層的 なオブジェクト指向トランザクション処理に対して, こ のプライオリティシーリングを適用して, 論文 $[1,2]$ が未 解決のままに残していた先着トランザクションの積み残 し現象を解決することを可能にした．我々がプライオリ ティシーリングをオブジェクト指向トランザクション処 理に導入した動機は，同一のオブジェクトをアクセスす る互換となるメソッドの組合せに対して，後着トランザ クションのメソッドの実行が先着トランザクションのメ ソッドの実行に部分的に先行することから発生しうる, 先着トランザクションの積み残し現象を回避して, オブ ジェクト指向トランザクション処理の性能を向上させる ためである [5-8].

本論文は，プライオリティシーリングによるオブジェ クト指向トランザクション処理のアルゴリズムを提案す る。オブジェクト指向トランザクション処理は，本質的 にサブトランザクションのスケジューリングとなる。こ のサブトランザクションのスケジューリングは, キュー におけるサブトランザクションのスケジューリングアル ゴリズムおよびロック予定表を用いた実行可能状態判 定アルゴリズムに従っておこなわれる．提案するプライ オリティシーリングによるオブジェクト指向トランザク ション処理のアルゴリズムは, 先着トランザクションの 積み残し現象の回避が可能となる。また, 提案するアル ゴリズムは，オブジェクト指向直列可能性なる性質を満 足することを示す.

本論文で提案したオブジェクト指向トランザクション 処理の手法の有効性を実証するために, 実験による性能 評価をおこなう。具体的には，優先度による従来のトラ ンザクション処理の積み残し分布の測定結果から，プラ イオリティシーリングの導入の必要性を確認したのち, トランザクションの実行時間，トランザクションの待ち 時間, サブトランザクションの一時停止時間などについ ての実験結果を踏まえて，プライオリティシーリングに よるオブジェクト指向トランザクション処理の性能評価
を検討する。

本論文の構成は次のとおりである．2. ではオブジェク ト指向トランザクション処理に関する木構造としてのモ デル，オブジェクト指向直列可能性および従来の処理手 法が抱える問題点について述べる. 3. では, プライオリ ティシーリングによるオブジェクト指向トランザクショ ン処理のアルゴリズムを提案するとともに，その性質を 示す. 4. では提案したオブジェクト指向トランザクショ ン処理に関していくつかの実験をおこない，提案方式の 性能評価について報告する.

\section{2. オブジェクト指向トランザクション処理}

\section{1 オブジェクト指向トランザクションモデル}

オブジェクト指向トランザクションの特徴は, オブジェ クトに付随するメソッドの再帰的な起動である. 言い換 えると, トランザクション $\mathrm{T}$ は, オブジェクト Oi のメ ソッド mi を起動すると, メソッド miでは, 再び, 他の オブジェクト Oij のメソッド mij を起動する.メソッド mi は，他のオブジェクトのメソッドを起動するのみなら ず，オブジェクト Oi を $\operatorname{read}(\mathrm{Oi})$ または write(Oi) する 操作をおこなう。なお，意味的並行処理制御においてオ ブジェクトをアクセスするメソッドは read および write に限らないが，一般性を失うことなく，本論文で使用す るメソッドは read および write に限定する。トランザク ションのプログラムの構造は次のように書ける.

$\mathrm{T}()\{$

object 1. method 1

object 2 .method2

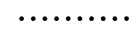

\}

$\operatorname{mi}()\{$

object 11 .method 11

object 12 .method12

..........

\}

オブジェクト指向トランザクションは, メソッドの再 帰的な起動の性質から，オブジェクトとそれをアクセス するメソッドの一対からなるノードから構成される木構 造としてモデル化される.オブジェクト指向トランザク ションでは, トランザクションは木であり, サブトラン ザクションはノードである. Fig.1にトランザクション の木構造を示す. Fig.1における記号として, Ti はトラ ンザクションを, Ti.j, Ti.j.kなどの記号はサブトランザ クションを意味する。また， A P P どはオブジェクト を示す. Fig.1において，同一のオブジェクトをアクセ 


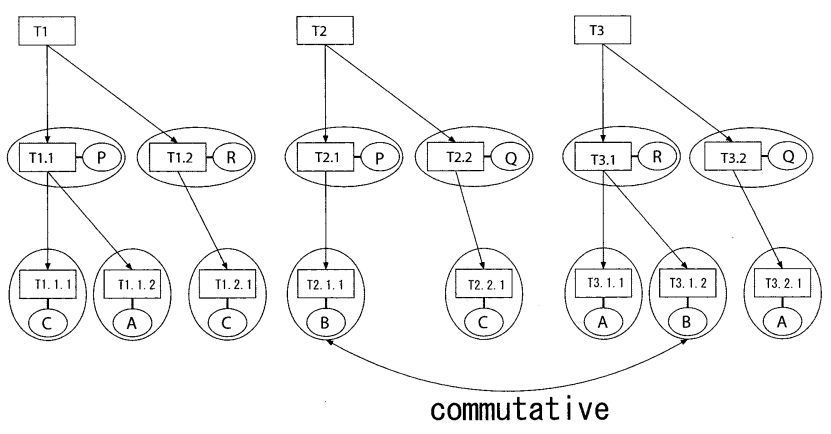

Fig. 1 Object-oriented transaction model

スする複数のメソッドの関係は，オブジェクトBに同時 にアクセスする場合のみを互換とし，B 以外の同一オブ ジェクトへの同時アクセスは衝突と仮定する。トランザ クションの木構造において, 根ノードから葉ノードに向 かって起動され，葉ノードから根ノードに向かって実行 される。また，木構造において，左側の部分木から右側 の部分木に向かって実行されるものとする．新たに到着 したトランザクションは，無条件に起動される。なお， 一般にトランザクションは定型業務のプログラムである ことから，スケジューラはトランザクションの構造につ いて既知であると仮定する。

\section{2 オブジェクト指向直列可能性}

オブジェクト指向直列可能性は, トランザクション処 理における古典的な直列可能性を拡張した概念である。 トランザクション処理は, 原子性, 一貫性, 孤立性, 耐 久性からなる ACID 特性が要求される [9-11] が, 直列可 能性はこの孤立性を具体化した概念であり，データベー スをアクセスするトランザクションが結果として直列に 処理されることを意味する．この直列可能性を保証する ために使用されるロックは，共有ロックと排他ロックに 区別される。

【定義 1】共有ロックは, あるトランザクションが読 み出し操作を行う場合に，その読み出し操作を保護する ロックであり，あるオブジェクトに対して複数の読み手 が孤立性を損なうことなく並行してアクセスすること ができる．排他ロックは，あるトランザクションが書き 込み操作を行う場合に，その書き込み操作を保護する ロックであり, 同時にそのオブジェクトに他のトランザ クションが読み出しまたは書き込み操作をすることを排 除する.

この 2 種類のロックを使用した直列可能性を保証する ために，互換と衝突の概念がある.

【定義 2】共有ロックと共有ロックは互換であるが, 共有ロックと排他ロック，または排他ロックと排他ロッ クは衝突する.

一方, オブジェクト指向トランザクションの並行処理 制御では，オブジェクトへのアクセスが互換となる局面 において, 木構造の先着トランザクションに木構造の後 着トランザクションを割り込ませるスケジューリングと
なるため, 古典的な直列可能性を単純に適用することは 困難となり，Rakow らは古典的な直列可能性をオブジェ クト指向直列可能性に次のように拡張した $[1]$.

【定義 3】トランザクション処理がオブジェクト指 向直列可能性であるとは，二つのサブトランザクション が衝突するとき, 先着のサブトランザクションを後着の サブトランザクションよりも先に実行させ，二つのサブ トランザクションが互換であるとき, 先着のサブトラン ザクションと後着のサブトランザクションとの実行順序 を問わずに実行させるスケジューリングを満たすことを いう.

\section{3 意味的並行処理制御の問題点}

意味的並行処理制御は, メソッドの再帰的な起動をお こなうオブジェクト指向トランザクションのスケジュー リングにおいて，オブジェクトを同時にアクセスするメ ソッドに関する意味情報を表すテーブルを参照すること により，並行処理の性能向上を図る手法である．ここで， テーブルのエントリには，指定されたオブジェクトに対 して, 同時アクセスする二つのメソッドが互換または衝 突のいずれかを特定した意味情報が格納されている.

意味的並行処理制御の概要を述べる。文献 [2]による と, オブジェクト指向トランザクション処理の特徵とし て, メソッドの起動およびオブジェクトへの直接アクセ スが共存することを挙げている，すなわち，親サブトラ ンザクションによる子サブトランザクションのメソッド を起動, 子サブトランザクションにおけるオブジェクト アクセス，親サブトランザクションにおけるオブジェク トアクセスの順序で実行される。本論文においても，こ の仮定のもとに議論を進める. なお, 本論文で使う実 行という用語は，このオブジェクトアクセスを意味す る. 先着トランザクション $\mathrm{T} 1$ と後着トランザクション $\mathrm{T} 2$ が並行処理の状態にあるとする. 一般性を失うこと なく, $\mathrm{T} 1$ のサブトランザクション $\mathrm{T} 1 . \mathrm{i} と \mathrm{~T} 2$ のサブト ランザクション $\mathrm{T} 2 . \mathrm{m}$ が同じオブジェクト P をアクセ スし，おのおののサブトランザクションの子となるサブ トランザクション T1.i.j と T2.m.n が同じオブジェクト $\mathrm{Q}$ をアクセスするものとする。意味的並行処理制御は, $\mathrm{P}(\mathrm{T} 1)>\mathrm{P}(\mathrm{T} 2)$ なるトランザクションの優先度に基づい て, オブジェクト指向直列可能性を満足するように, 親 サブトランザクションおよび子サブトランザクションが 互換または衝突となる組合せに応じてスケジューリング される。

- T1.i と T2.m が互換であり, T1.i.j と T2.m.n が衝 突するとき, T1.i.jを実行完了した後, T1.i と T2.m の実行順序は問わない.

• T1.i と T2.mが衝突し, T1.i.j と T2.m.n も衝突する とき, T1.i.jを実行完了して, さらにT1.i と T2.m.n を実行完了した後, 初めて T2.mを実行できる.

- T1.i と T2.m が互換であり, T1.i.j と T2.m.nも互 
換であるとき, T1.i.j と T2.m.nの実行順序は問わな い.また, T1.i.jとT2.m.nを実行完了した後, T1.i と T2.mの実行順序は問わない.

• T1.i と T2.m が衝突し, T1.i.j と T2.m.nが互換で あるとき，T1.i.j と T2.m.nの実行順序は問わない. また，T1.i.jとT2.m.nを実行完了して，さらにT1.i を実行完了した後, 初めて T2.m を実行できる.

Muth らは，オブジェクト指向直列可能性の定義 [1]に 従って意味的並行処理制御を提案したが $[2]$, 彼らの提案 した意味的並行処理制御には問題点が存在した。すなわ ち，オブジェクト指向直列可能性の定義に従うと, オブ ジェクトへのアクセスが互換となるサブトランザクショ ンの実行順序を問わないため，先着トランザクションの 実行完了に先んじて，後着トランザクションにおけるサ ブトランザクションの部分的な実行を許すことになる。 このとき, 後着トランザクションの部分的な実行が完了 しても，先着トランザクションの実行が完了する前に， さらに新たな後着トランザクションに対して，そのトラ ンザクションに拈ける互換となるサブトランザクション が先行して実行されるため，先着トランザクションは実 行をさらに延期されることを余儀なくされて，長時間に わたり実行完了することができない現象が生ずる。こ のように，先着トランザクションにおける互換となるサ ブトランザクションの積み残し現象が未解決問題として 残っていた。

\section{3. オブジェクト指向トランザクション処 理アルゴリズム}

\section{1 プライオリティシーリング}

我々が目標とすべき課題は, 後着トランザクションに 先着トランザクションへの割り込みを許しながら，先着 トランザクションの積み残しを解消することである。こ のため，プライオリティシーリングによるオブジェクト 指向トランザクション処理のアルゴリズムを提案する. なお，ACID 特性のうち，原子性，一貫性，耐久性は満 たされると仮定する。孤立性については，提案するアル ゴリズムがオブジェクト指向直列可能性を満たすことを 示す. 本論文では，優先度を使う意味的並行処理制御を 従来手法とよび，提案する手法をプライオリテイシーリ ング手法とよぶことにする。まず，プライオリティシー リングの定義を記す。

【定義 4】オブジェクトのプライオリティシーリング は，対象となるオブジェクトをアクセスする複数のトラ ンザクションに付加された優先度のなかで, 最高の優先 度である。

定義 4 から，Fig.1の木構造で表現されるオブジェクト 指向トランザクションモデルに対応するプライオリティ シーリングは, Table 1のようになる. 表において, 記 号 Objはオブジェクトを, PCはプライオリティシーリ ングを示す。ここで, 三つのトランザクションは, $\mathrm{T} 1$,
$\mathrm{T} 2$ ， T3 の時間順に到着するため, トランザクションの 優先度は, $\mathrm{P}(\mathrm{T} 1)>\mathrm{P}(\mathrm{T} 2)>\mathrm{P}(\mathrm{T} 3)$ である。

Table 1 Priority Ceiling (PC)

\begin{tabular}{|l|l|l|l|l|l|l|}
\hline Obj & A & B & C & P & Q & R \\
\hline PC & $\mathrm{P}(\mathrm{T} 1)$ & $\mathrm{P}(\mathrm{T} 2)$ & $\mathrm{P}(\mathrm{T} 1)$ & $\mathrm{P}(\mathrm{T} 1)$ & $\mathrm{P}(\mathrm{T} 2)$ & $\mathrm{P}(\mathrm{T} 1)$ \\
\hline
\end{tabular}

\section{2 プライオリティシーリングによるトランザ} クション処理アルゴリズム

オブジェクト指向トランザクション処理は, 以下に示 すスケジューリングルールを基本方針とする.

[スケジューリングルール]

- 優先度はすべてのトランザクションに付加され，ト ランザクションの到着順に優先度を降順に設定する.

・衝突するサブトランザクション間の実行順序は，当 該のサブトランザクションが属するトランザクショ ンの優先度に従う。

・互換であるサブトランザクションに対して，プライ オリティシーリングが高いオブジェクトをアクセス するサブトランザクションを優先的に実行する.

このスケジューリングルールを実現するため, オブ ジェクト指向トランザクション処理は Fig. 2 に示すアル ゴリズムに従う.オブジェクト指向トランザクション処 理は，複数のトランザクションのサブトランザクション を切り替えながら実行される.このため, キュー内のサ ブトランザクションのスケジューリングは, オブジェク ト指向トランザクション処理において最も重要な役割を 果たす．Fig.3に示す，キューに拈けるサブトランザク ションのスケジューリングは，ロック予定表を用いた実 行可能状態判定アルゴリズムに従っておこなわれる。こ の実行可能状態の判定アルゴリズムを Fig.4に示す.こ こで使用するロック予定表は，各オブジェクトに対して ロックを予定するサブトランザクション識別子，および， 共有ロックまたは排他ロックを示すロックモードが記入 される。オブジェクトに対するサブトランザクション識 別子およびロックモードの更新は, Fig.5 に示すロック 予定表の作成アルゴリズムに従う。このロック予定表は, トランザクションの到着に応じて動的に変化する．ある 時点に扮けるロック予定表の例を Table 2 に示す.

Table 2 Lock table

\begin{tabular}{|l|l|l|l|l|l|l|l|}
\hline Obj & A & B & C & D & E & F & G \\
\hline Lock & Exl & Shr & Shr & Exl & Exl & Exl & Exl \\
\hline ID & T12 & T311 & T32 & T112 & T312 & T2 & T222 \\
\hline
\end{tabular}

オブジェクト指向トランザクション処理のアルゴリズ ム（Fig.2）の主要な流れを記す.トランザクション $\mathrm{Ti}$ が新たに到着すると，実行中のサブトランザクションの 存否をチェックして, 存在すれば実行中のサブトランザ クションは一時停止される. 到着したトランザクション Tiが起動され, Tiに係るオブジェクトのプライオリティ 


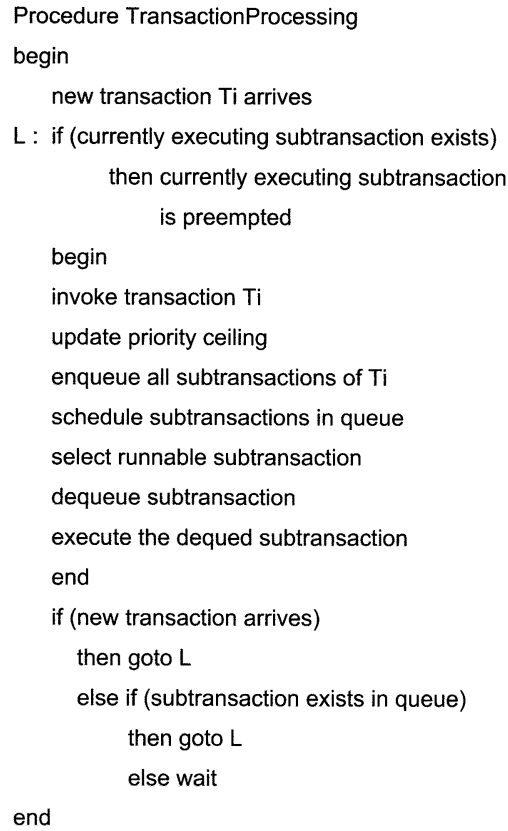

Fig. 2 Object-oriented transaction processing algorithm シーリングは更新され，Ti のサブトランザクションは キューに格納される。ささらに、キュー内のサブトランザ クションはスケジューリングされ, 実行可能なサブトラ ンザクションが選ばれる。この選ばれたサブトランザク ションはキューから取り出されて，実行される．Fig.2 のアルゴリズムにおけるキュー内のサブトランザクショ ンのスケジューリングについての詳細なアルゴリズムを Fig.3に示す.

キューにおけるサブトランザクションのスケジューリ ングアルゴリズム（Fig.3）の主要な流れを記す。スケ ジューリングの開始時点で, キューの先頭にポインタを セットする．すべてのサブトランザクションの予定ロッ クをチェックしたのち，キュー内のポインタが指すサブ トランザクションを取得する.つぎに，当該サブトラン ザクションが未完了な子サブトランザクションをもたず， 実行可能状態判定アルゴリズムによりロック予定表を参 照して実行可能状態と判定されたとき, そのサブトラン ザクションを実行可能変数 allowed-exeに格納する。未 完了な子サブトランザクションをもたないことのチェッ クは, 2.3 の意味的並行処理制御において子サブトラン ザクションを実行完了したのち，親サブトランザクショ ンを実行することに対応する。ささらに，キュー内にポイ ンタにより指された最後のサブトランザクションが存在 するとき，実行可能変数をキューから取り出して実行す る. キュー内のポインタが最後のサブトランザクション を指さないとき，ポインタをインクレメントして，その ポインタに指されるサブトランザクション Tijを一時変 数 allowed-tmp に格納する。Tijのすべての子サブトラ ンザクションが実行されているならば，実行可能状態判 定アルゴリズムにより, Tijが実行可能であるか否かを判

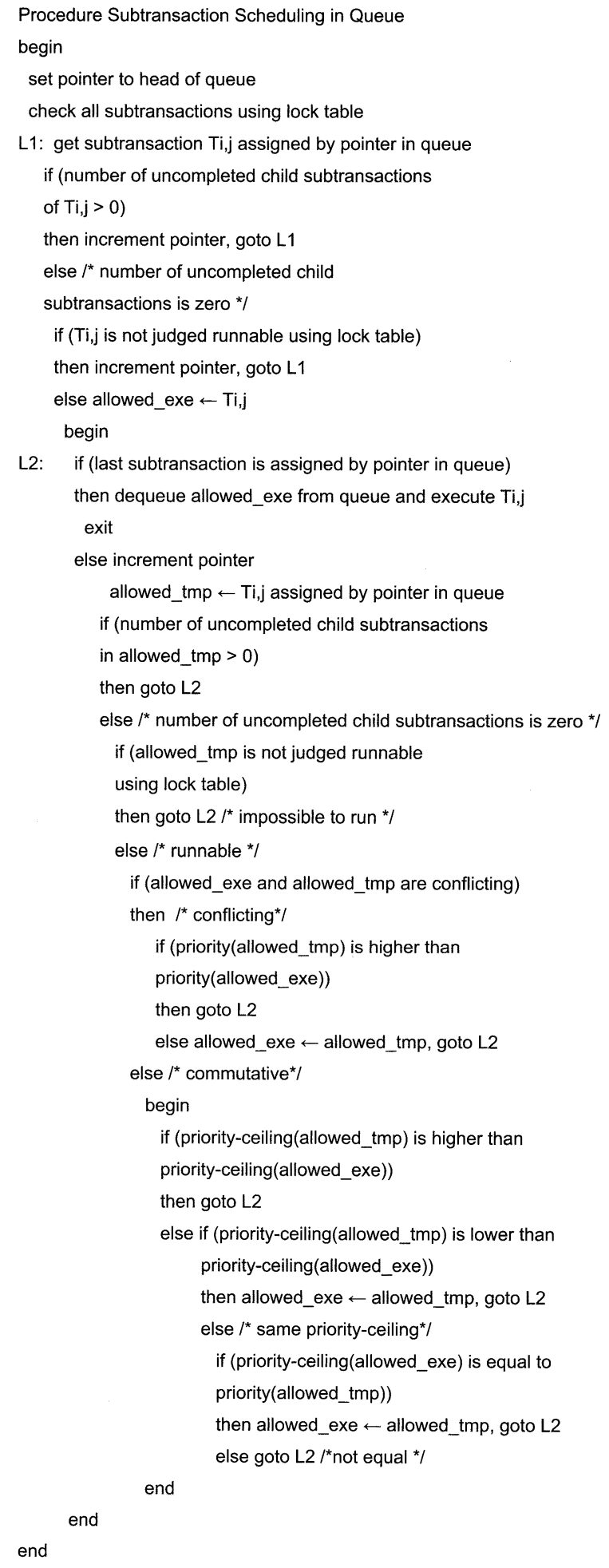

Fig. 3 Subtransaction scheduling algorithm in queue 定する. 実行可能である場合, 実行可能変数と一時変数 に格納されている二つのサブトランザクションが衝突ま たは互換のいずれかにより，処理が異なる． allowed-exe と allowed-tmp が衝突するならば，優先度の高い方を allowed-exe とする. 両者が互換かつプライオリティシー リングが等しく, allowed-exeがアクセスするオブジェク トのプライオリティシーリングが allowed-tmp が属する 


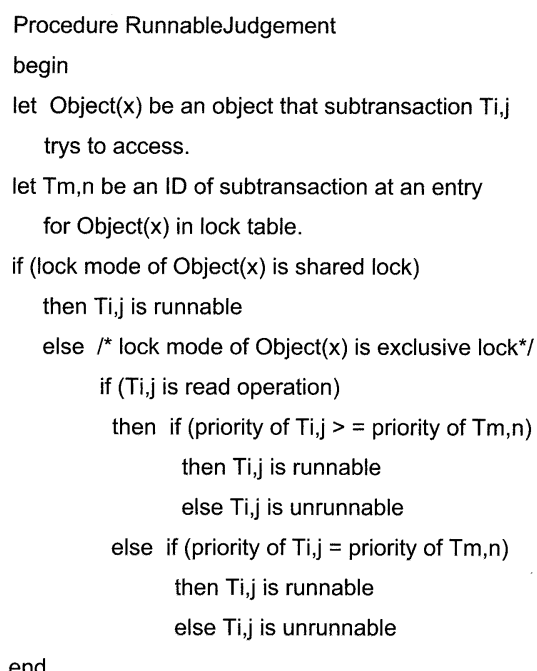

Fig. 4 Runnable status judgement algorithm

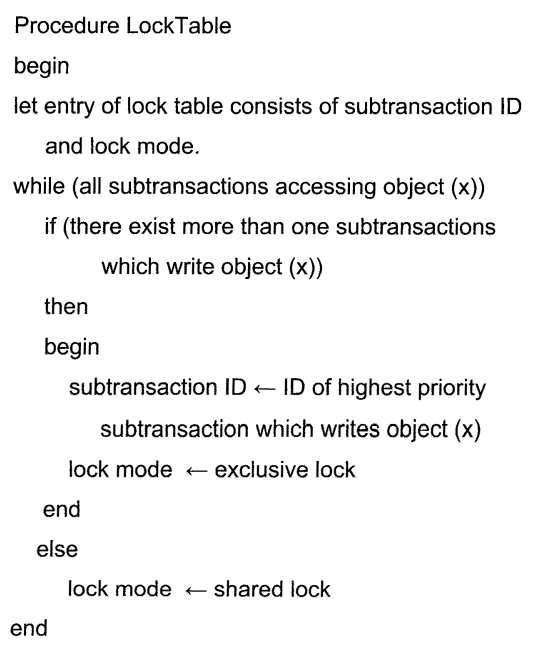

Fig. 5 Lock table generating algorithm

トランザクションの優先度に等しい場合, allowed-tmp を新たに allowed-exeと置き換えて allowed-exeを実行す る。これは, allowed-tmpが属するトランザクションの 優先度が allowed-exeが属するトランザクションの優先 度より高いことを意味する。両者が互換かつプライオリ ティシーリングが等しく, allowed-exeがアクセスするオ ブジェクトのプライオリティシーリングが allowed-tmp が属するトランザクションの優先度に等しくない場合に は，allowed-exeを実行する。言い換えると，いずれの 場合も，プライオリティシーリングが等しければ，サブ トランザクションはトランザクションの到着順に従って 実行される。

実行可能状態判定アルゴリズム（Fig.4）の概要を記 す。ロック予定表に抽て, オブジェクトxのアクセス を予定するサブトランザクション Tmnの情報があらか じめ格納されていると仮定する。また，サブトランザク ションTijがオブジェクトxのアクセスを新たに予定し ているとする。ロック予定表におけるオブジェクトxの
ロックモードが共有ロックならば，サブトランザクショ ン Tij は実行可能である.オブジェクトxのロックモー ドが排他ロックならば，Tij が読み出し操作であり，サ ブトランザクション Tijが同じオブジェクトをアクセス するサブトランザクション Tmn より優先度が高いとき, Tij は実行可能である.一方, Tijが書き込み操作であり, サブトランザクション Tijが同じオブジェクトをアクセ スするサブトランザクション Tmn と優先度が等しいと き，Tij は実行可能である.

ロック予定表の作成アルゴリズム（Fig.5）の概要を記 す。オブジェクトxに書き込みをおこなうサブトランザ

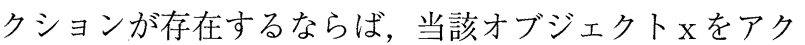
セスする最高の優先度を持つサブトランザクションの識 別子をロック表におけるオブジェクトxのサブトランザ クション項目に代入して，オブジェクトxのロックモー ドを排他ロックとする.オブジェクトxを読み出すサブ トランザクションのみが存在するならば，オブジェクト $\mathrm{x}$ のロックモードを共有ロックとする。この操作を，才 ブジェクトをアクセスするすべてのサブトランザクショ ンに対して繰り返す.

Figs.2-5に提案するアルゴリズムと既存の方式との大 きな相違点は, 先着トランザクションにおけるサブトラ ンザクションの積み残しの解消を図って，互換となるア クセスに対してプライオリティシーリングを適用してい ることである.

\section{3 提案手法の性質}

オブジェクト指向トランザクション処理に関する提案 手法は, オブジェクト指向直列可能性について次の性質 を満なす。

【定理 1】 プライオリテイシーリングによるオブジェ クト指向トランザクション処理は, オブジェクト指向直 列可能性を保証する。

（証明）到着した $n$ 個のトランザクションが並行処理 制御されており，それらの中で $i$ 個のトランザクションの サブトランザクションがオブジェクト O 1 をアクセスす る候補と仮定する。トランザクションの優先度は, 到着 順が早いほど高くなる。オブジェクト $\mathrm{O} 1$ へのアクセス が衝突するとき， 3.2 のスケジューリングルールにより， 優先度が高いトランザクションのサブトランザクション が実行される．さらに同時に，別の $j$ 個のトランザクショ ンのサブトランザクションがオブジェクト O 2 をアクセ スしようとして，これらのアクセスが衝突するとき，O1 および $\mathrm{O} 2$ おのおのに対する最高の優先度を持つ二つの トランザクションのうち, 高い優先度のトランザクショ ンのサブトランザクションが実行される。つぎ，O1 お よび $\mathrm{O} 2$ に対するアクセスが共に互換であるとする．定 義 4 より，オブジェクトのプライオリティシーリングは, 対象となるオブジェクトをアクセスする複数のトランザ クションに付加された優先度のなかで，最高の優先度で 
ある. 3.2 のスケジューリングルールにより，互換であ るサブトランザクションに対して，プライオリティシー リングが高いオブジェクトをアクセスするサブトランザ クションが優先的に実行される.さらに Fig.3のキュー におけるサブトランザクションスケジューリングアルゴ リズムから，オブジェクト O1のプライオリティシーリ ングが O2 のプライオリティシーリングより高いとする と, O1 をアクセスする最も早く到着したトランザクショ ンのサブトランザクションが実行される。なお，複数の トランザクションが並行処理制御される状況においても, Fig.3のキューにおけるアルゴリズムに従って，二つのサ ブトランザクションを比較して実行される，上記のスケ ジューリングは, 二つのサブトランザクションが衝突す るとき，先着のサブトランザクションを後着のサブトラ ンザクションより先に実行させ，二つのサブトランザク ションが互換であるとき, 先着のサブトランザクションと 後着のサブトランザクションの実行順序を問わないため, オブジェクト指向直列可能性の定義は満たされる。

\section{4. 性能評価}

\section{1 実験環境}

提案するプライオリテイシーリングによるトランザク ション処理および従来手法である優先度による意味的並 行処理制御との比較のため, 再帰的にメソッド起動をお こなう木構造のトランザクションに対して，3. で提案し たプライオリティシーリングによるトランザクション処 理アルゴリズムを実行して性能評価をおこなった。実験 環境をTable 3 に示す。

Table 3 Experimental environment

\begin{tabular}{|l|l|l|}
\hline CPU & Pentium4 & $1.5 \mathrm{GHz}$ \\
\hline Memory & SDRAM & $512 \mathrm{MB}$ \\
\hline HDD & Western Digital & $\begin{array}{l}\text { IDE 20GB, } \\
7200 \mathrm{rpm}\end{array}$ \\
\hline OS & Windows2000 & Professional \\
\hline Language & Java2 SDK1.4.1 & \\
\hline
\end{tabular}

\section{2 実験におけるパラメータ}

本論文で提案したプライオリティシーリングによるト ランザクション処理手法の有効性を実証するため, write 率の変動による実験および使用率の変動による実験をお こなった，前者を write率テスト，後者を使用率テスト とよぶことにする，使用率テストとして，使用率テスト 1 および使用率テスト 2 の 2 種類の実験をおこなった。こ こでは，write率テストおよび使用率テスト 1 に掠ける 実験条件としての各パラメータの数值を Table 4 に示す. なお，後で説明する使用率テスト 2 における実験条件は 異なるが，パラメータの意味は同じである。

性能評価の実験におけるパラメータの意味を以下に列 記する。
Table 4 Parameters in write ratio test and CPU use ratio test1

\begin{tabular}{|c|l|l|}
\hline Parameters & $\begin{array}{l}\text { Write ra- } \\
\text { tio test }\end{array}$ & $\begin{array}{l}\text { CPU use } \\
\text { ratio test1 }\end{array}$ \\
\hline Num. of transactions & 100 & 100 \\
\hline Num. of subtransactions & 7 & 7 \\
\hline Execution time/sub_tr [ms] & 100 & 100 \\
\hline Num. of data items & 7 & 12 \\
\hline Write ratio (percentage) & $0 \sim 100$ & 80 \\
\hline CPU use ratio (percentage) & 80 & $5 \sim 100$ \\
\hline
\end{tabular}

・トランザクション数は, 1 回のテストで発生させる トランザクション数である.

・サブトランザクション数は, 一つのトランザクショ ンを構成するサブトランザクション数である．実験 では，Fig.6のトランザクションモデルに対応する， 七つのサブトランザクションを含む 3 階層木構造モ デルを採用する。

・サブトランザクションの実行時間は，サブトランザ クション 1 個あたりの書き込み, および読み出し処 理にかかる時間である。実験では，比較を行いやす くするために，この実行時間をすべて一定とする.

・トランザクションの実行時間は, サブトランザク ションの実行時間の総和にトランザクションの待ち 時間，トランザクションの一時停止時間，およびス ケジューリングオーバヘッドによる時間を加算した 值である.

・トランザクションの待ち時間は, トランザクション が到着してから処理が開始されるまでの時間であ る. サブトランザクションの待ち時間は, トランザ クションの待ち時間をサブトランザクションの個数 で割った值である.

・トランザクションの一時停止時間は, 他のトランザ クションの割り込みによりサブトランザクションが 処理を中断されてから処理を再開されるまでの時間 の総和である。サブトランザクションの一時停止時 間は, トランザクションの待ち時間をサブトランザ クションの個数で割った值である.

・データ項目数は, サブトランザクションがアクセス するデー夕項目の個数である。デー夕項目は属性を 選択することによりアクセスするデータベースの部 分である。データベースは，オブジェクトを構成す る要素における，クラスに対応しないデータの集ま りである.デー夕項目数が少ないほど衝突する可能 性が高くなる。ただし，トランザクションモデルに おいて，同一トランザクション内で同一デー夕項目 にアクセスしないと仮定しているため，最低 7 個必 要となる。

・ write率は, サブトランザクション 100 個を $100 \%$ と したときに，書き込み操作が占める割合である。サ 
ブトランザクションの書き込み操作・読み出し操作 は基本的にランダムに設定されるが, write率は互 換・衝突の起こる確率を調整するための指標である. たとえば，write率が $50 \%$ の場合，100 個のサブト ランザクション中，50個のサブトランザクションを 書き込み操作としてランダムに選択し，残りは読み 出し操作となるように設定する.

・使用率は，対象時間帯においてコンピュータがトラ ンザクションを処理している時間の割合である．たと えば，1トランザクションを処理するのに平均 100 ミ リ秒かかり，1分あたりに到着するトランザクション の数を 200 個とする.このとき，480個を処理するの にかかる時間は $100 \times 480=48,000$ ミリ秒と推定され るため，1分あたりの利用率は 48,000/60,000=80\% となる。使用率は，同時実行処理数を間接的に表す 指標と見なすことができる。なお，トランザクショ ンの到着間隔時間は，使用率を用いて，ポアソン分 布によってランダムに発生させている。

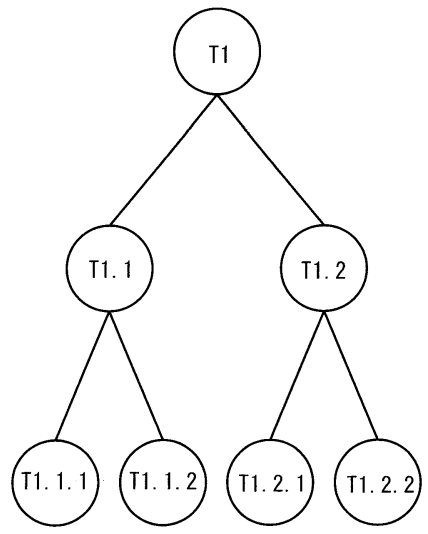

Fig. 6 Transaction model in experiment

\section{3 実験結果}

\subsection{1 write 率テストおよび使用率テスト 1}

write率テストおよび使用率テスト 1 の概要を述べる. write 率テストは, write率の変動による性能評価をお こなう。write率を 0～100\%まで，5\%ずつ変動させ，従 来手法，プライオリティシーリング手法それぞれにおい て 21 回, 計 42 回のテストを行う。デー夕項目数は最低 数の 7 個とする. 使用率は, 並行処理制御におけるスケ ジューリングのテストである以上，ある程度の同時実行 数を確保するために $80 \%$ と設定する．また，使用率テス ト 1 は，使用率の変動による性能評価をおこなう。使用 率を 5〜100\%まで，5\%ずつ変動させ，従来手法，プラ イオリティシーリング手法それぞれにおいて 20 回，計 40 回のテストをおこなう。提案するプライオリティシー リング手法は，互換な組合せにおいて従来手法と異なっ たスケジューリングをおこなうため，互換となる確率を ある程度高くする。このために，オブジェクト数は 12 個，write率は $50 \%$ と設定する，write率テストおよび使
用率テスト 1 は，主に次の三つの項目について性能評価 を行う。

・トランザクションの実行時間

・トランザクションの積み残し

・サブトランザクションの待ち時間および一時停止 時間

\subsection{2 write 率の影響}

まず，write率によるトランザクション当りの平均実 行時間を Fig.7 に示す。図の横軸はwrite 率を，縦軸は 平均実行時間をミリ秒単位で表す，従来手法による平均 実行時間の実験結果は，write率が低い0３0\%付近にお いて激しい変動を示す. write率が $5 \%$ 刻みで増加する場 合，平均実行時間の増減は約 $\pm 3 \sim 16000$ ミリ秒となり， 平均 3451.95 ミリ秒の増減となる。これは, write率の低 さ，つまり互換となる組合せの多さが原因と考えられる。 すなわち，従来手法において，互換の場合にサブトラン ザクションの実行候補が任意に選ばれるため, 到着順が 考慮されないスケジューリングがおこなわれる結果，積 み残しが発生する割合が高くなる。これに対して，プラ イオリティシーリング手法は, write 率が変動しても安 定している。 write率が5\%刻みで増加する場合，平均実 行時間の増減は約 $\pm 3 \sim 120$ ミリ秒となり，平均 19.1 ミ リ秒の増減である。従来手法に比べて，プライオリティ シーリング手法は安定していると同時に，全体を通して 実行時間が短くなり，効率の良い処理が可能となる．特 に write率が低い場合は，その傾向が顕著である．プラ イオリティシーリング手法においては，全テストを通し て積み残しが一度も発生せず，従来手法に対するプライ オリティシーリング手法の優位性を示している.

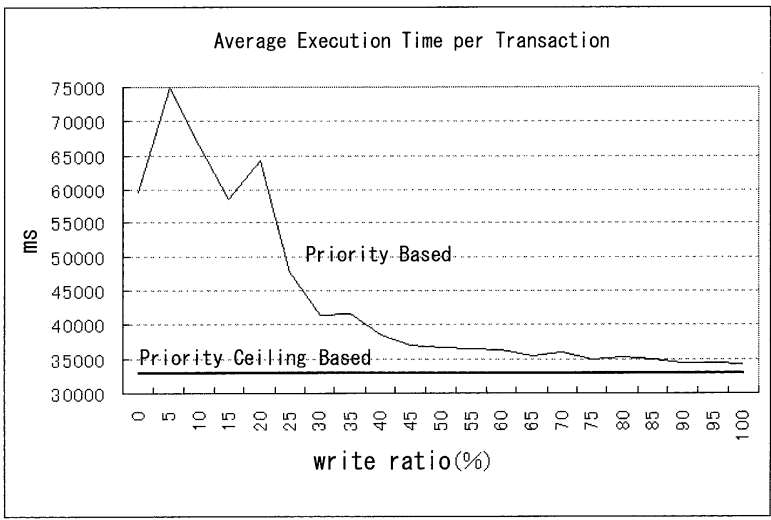

Fig. 7 Average execution time per transaction vs write ratio for write ratio test

つぎに, write率を変化させてサブトランザクション の積み残し分布を求める実験を, 従来手法のトランザク ション処理によりおこなった。この実験により，プライ オリティシーリングを使わない従来手法が不安定である 理由は積み残しが原因であることを実証する. Figs.8 10 は, write率 15\%，30\%，45\%のテストにおけるトラ ンザクションの実行完了順序を分布図で示している。横 
軸はトランザクション ID, 縦軸は実行完了順序の番号 を表している．トランザクション ID は到着順に付され るため, 到着順通りに積み残されることなく実行完了さ れた場合の分布を理想直線で表した。この直線より上の 部分に分布していることは積み残されていることを意味 し, また, 理想直線から離れるほど積み残しの度合いが 大きいことを意味する。

write 率 15\%の実験結果（Fig.8）から，100個のトラ ンザクションのうち 36 個のトランザクションが積み残 され，積み残し度合いも大きいことが観察される。こ れは，write率が $15 \%$ ，つまり $85 \%$ のトランザクション が互換の組合せになり，大部分のトランザクションが任 意順での実行となっていることが原因と考えられる。こ のように, Fig.8の結果は未だ理想直線とはかけ離れて おり，積み残しは無視できるレベルではない，つぎに，

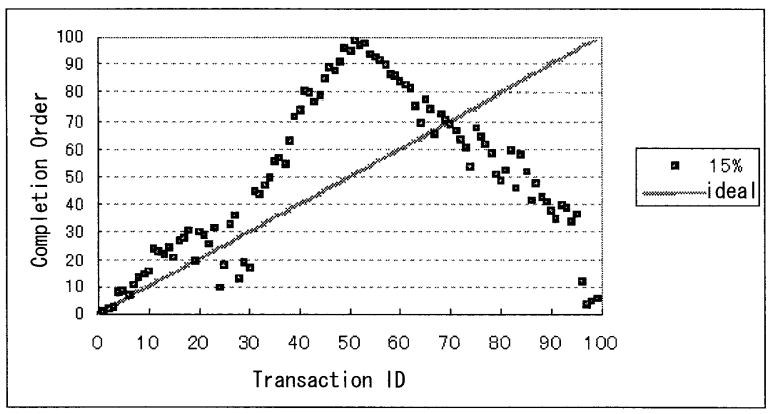

Fig. 8 Left-off subtransactions with write ratio of 15 percentage

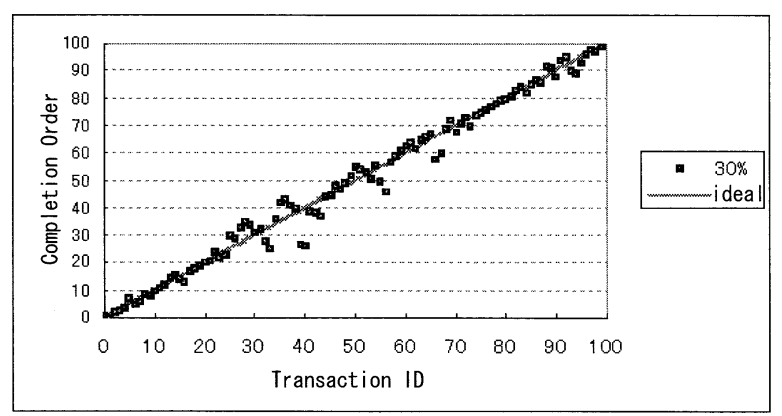

Fig. 9 Left-off subtransactions with write ratio of 30 percentage

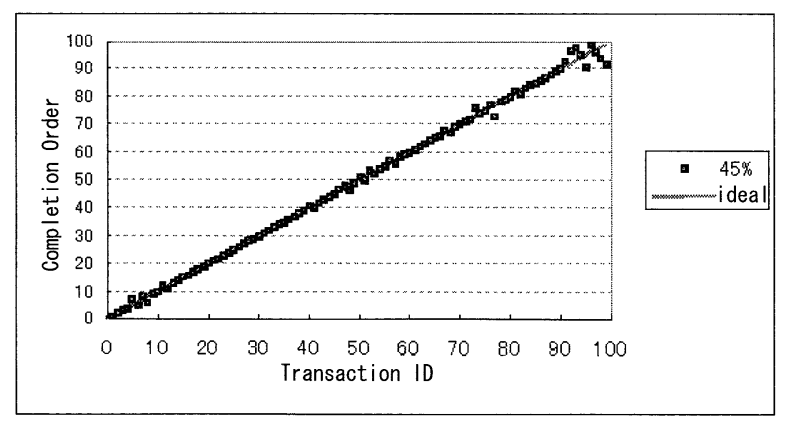

Fig. 10 Left-off subtransactions with write ratio of 45 percentage write 率 30\%の実験結果（Fig.9）は，100個のトランザ クションのうち 29 個のトランザクションが積み残され ているが, 積み残し分布もかなり理想直線に近づき, 積 み残し度合いはかなり小さくなることが見て取れる。さ らに, write率 45\%の実験結果（Fig.10）は，100個のト ランザクションのうち 15 個のトランザクションが積み 残されているが，ほぼ理想直線と同じ分布となることが わかる. 再度, Fig.7の write率によるトランザクション 当りの平均実行時間グラフを見ると, この $45 \%$ 付近から 実行時間が安定し始めている。これらの結果から, 従来 手法のトランザクション実行時間の不安定さは, 積み残 しが原因であることが実証された。

\subsection{3 使用率テスト 1: 互換と衝突が混在する場合}

互換と衝突が混在する場合の使用率の影響について 実験した。まず，トランザクション当りの平均実行時間 を従来手法とプライオリテイシーリング手法について対 比した実験結果を Fig.11 に示す. 使用率テスト 1 では, デー夕項目を 12 個, write率を $50 \%$ に設定しているため, 互換の組合せが高いものと考えられる。よって, write率 の結果から，プライオリティシーリング手法が従来手法 より効率が良いことが予想される．Fig.11は，使用率が 高くなると共にプライオリティシーリング手法の高い効 率性を示している. 使用率 $30 \%$ 付近から両手法ともに変 動が激しいのは, 到着時間をランダムに発生させている ため, 同時実行サブトランザクション内での互換・衝突 の割合が変化することが原因であると考えられる。また， 使用率が上がると共に，両手法が全体的に平均実行時間 が長くなっているのは, 同時実行数が増えるためである. 全体として，使用率に関わらず，プライオリティシーリ ング手法は従来手法より優れていることがわかる.

さらに, 効率がどの程度良いかを比較するために, 使 用率による平均実行時間差に対して, 従来手法の平均 実行時間を $100 \%$ とした時の割合をFig.12に示す．図か ら, 使用率が変動してもプライオリティシーリング手法 は従来手法より効率が良いといえる。とくに使用率 30〜 $70 \%$ は十分効率が良くなっており, 最低でも $10 \%$ 効率 が良いことが見て取れる，さらに詳しく見ると，使用率 が上がると共に, 効率が徐々に良くなるが, 後半はまた 下がっていく，これは，使用率の低い付近は，同時実行 数が少ないためにプライオリティシーリング手法の効果 があまり発揮されていないためであり，使用率が高い付 近の值が低いのは, 同時実行数が多いために, 衝突する 組合せ数が増えたことが原因であると考えられる.

サブトランザクション当りの平均一時停止時間と平均 待ち時間を Figs.13,14に示す。トランザクション当りの 平均実行時間において, 常に従来手法よりプライオリ ティシーリング手法の方が短縮されていたため, サブト ランザクションの平均一時停止時間・待ち時間も従来手 法より短縮されると予想された。 しかし, Figs.13,14を 


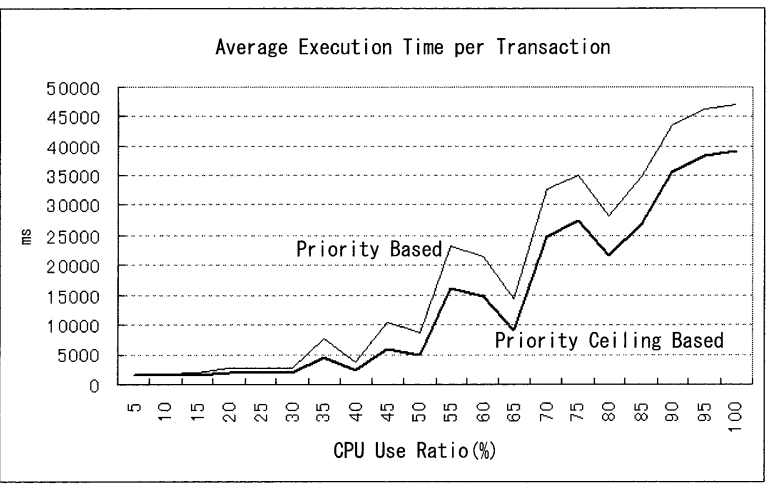

Fig. 11 Average execution time per transaction vs CPU use ratio for test1

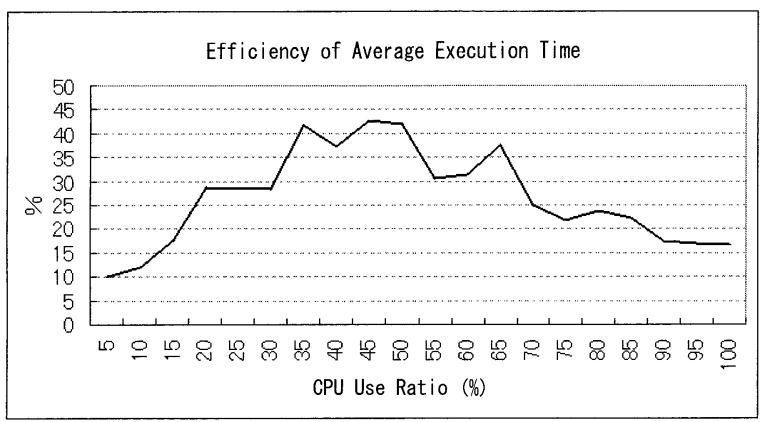

Fig. 12 Efficiency of average execution time per transaction vs CPU use ratio for test 1

見ると，一時停止時間については従来手法の方が值が小 さく，一時停止時間および待ち時間共に，双方の手法間 の時間差が小さい. わかりやすくするため, 一時停止時 間および待ち時間についておのおの, 従来手法の值か らプライオリティシーリング手法の值を差し引いた值を Fig.15に示した。これらの時間差が正の值のとき，プ ライオリティシーリング手法が従来手法より時間が短く なり，効率が良いことになる．Fig.15から，プライオリ ティシーリング手法は, 従来手法と比べて, 到着してか らすべての子サブトランザクションが実行完了する時間 は早くなるが，実行可能状態になるのが早い分，実行候 補として選ばれるのは遅くなると解釈できる。この現象 は，積み残しが関係していると考えられる，プライオリ ティシーリング手法においては積み残しが発生しないた め，ほぼ到着順に従って子サブトランザクションが実行 され, 実行可能状態になる。さらに, 実行候補として選 ばれるのも到着順に従う。一方, 従来手法では, 積み残 しが発生することから, 子サブトランザクションが実行 候補に選ばれず積み残されるために, 待ち時間が長くな ると考えられる。しかし, 到着順に従っていない分, 一 時停止時間としては思っていたより早く実行候補に選ば れる，または，待ち時間が長くなった分だけ一時停止時 間が短くて済むなどの原因が考えられる。

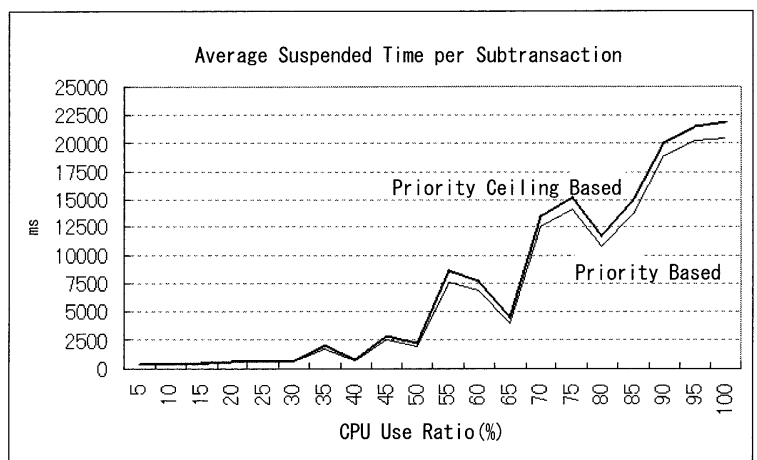

Fig. 13 Average suspended time per subtransaction vs CPU use ratio for test 1

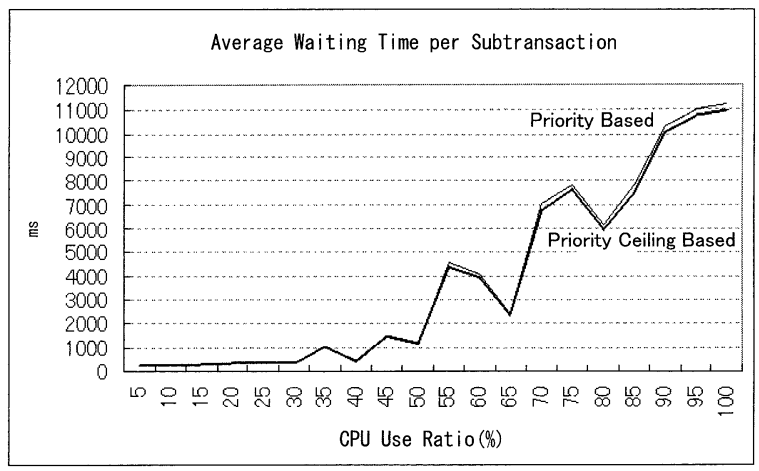

Fig. 14 Average waiting time per subtransaction vs CPU use ratio for test1

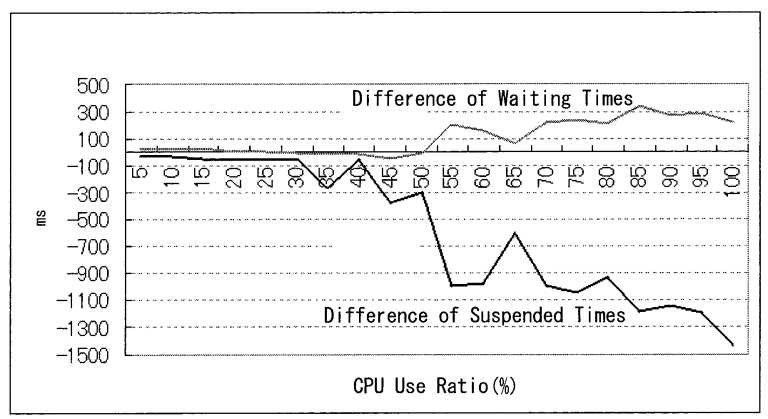

Fig. 15 Difference between average suspended time and average waiting time vs CPU use ratio for test1

\subsection{4 使用率テスト 2: 互換のみの場合}

さらに詳しく考察を加えるために，新たに使用率テス ト2を行った。使用率テスト 2 は, 主に次の二つの項目 について性能評価を行う。

・トランザクションの実行時間

・サブトランザクションの待ち時間および一時停止 時間

前回の使用率テスト 1 では, デー夕項目数が 12 , write 率が $50 \%$ で，互換となる確率が高いとはいえ，衝突が起 こる可能性もあった。よって, 互換・衝突の起こる確率が 結果に影響してしまい, 使用率のみによる変化がわかり にくかった。そこで，プライオリティシーリングの有用 性を実証するためには互換の起こる確率がより高い必要 
があることから，今回の使用率テスト 2 では，オブジェ クト数を 7 , write率を $0 \%$ に, 互換の組合せのみ起こ るように設定した．実験条件であるパラメータの数值を Table 5 に示す.

Table 5 Parameters in CPU use ratio test2

\begin{tabular}{|c|c|}
\hline Parameters & CPU use ratio test2 \\
\hline Num. of transactions & 100 \\
\hline Num. of subtransactions & 7 \\
\hline Execution time/sub_tr [ms] & 100 \\
\hline Num. of data items & 7 \\
\hline Write ratio (percentage) & 0 \\
\hline CPU use ratio (percentage) & $5 \sim 100$ \\
\hline
\end{tabular}

まず，トランザクション当りの平均実行時間を従来手 法拉よびプライオリティシーリング手法について比較し た実験結果を Fig.16に示す，図を見ると，使用率テスト 1 と同様に, 使用率に関わらずプライオリティシーリン グ手法が優れている.これは, write率テストにおいて実 証したように，互換の組合せのみが起こるため，プライ オリティシーリング手法の効率の良さが発揮された結果 である. 詳しく見ると, 従来手法とプライオリティシー リング手法との差が，使用率が上がるとともに大きく なっていることがわかる.ささらに, 使用率による平均実 行時間差に対して, 従来手法の平均実行時間を $100 \%$ と したときの割合をFig.17に示す。この図を見ると，プラ イオリティシーリング手法の効率が良くなっていること がわかる. しかし, 今回のテストでも後半, 少しではあ るが効率が落ちる。これは, 同時実行数が非常に多くな ると，プライオリティシーリングが高くても，対象とな るオブジェクトにアクセスを予定しているサブトランザ クションが増大するために, 到着順の遅いサブトランザ クションはどうしても実行完了が遅れてしまう。これに 対して従来手法では, 互換であるサブトランザクション の実行は任意の順序で選ばれるため, 実行時間の短い場 合が発生し, 両手法の実行時間差が縮まるものと考えら れる，従来手法に扮ける更に悪い状況の可能性を考慮す れば，プライオリティーシーリング手法は使用率の増加 に対しても十分な有効性があるといえる.

つぎに，サブトランザクション当りの一時停止時間扔 よび待ち時間についておのおの, 従来手法の值からプラ イオリティシーリング手法の值を差し引いた值を Fig.18 に示す. 図から, 使用率 $40 \%$ 以下のゾーンでは, 使用率 テスト1（Fig.15）と同様に, プライオリティシーリング 手法が従来手法に比べて, 一時停止時間が短く, 待ち時 間が長い傾向が読み取れる。しかし，使用率 $40 \%$ 以降に おいて, その傾向は, 常に満足されるとは限らない。言 い換えると, 4.3.3の考察で述べた, プライオリティシー リング手法においては, 到着してからすべての子サブト ランザクションが実行完了する時間は早いが, 実行可能

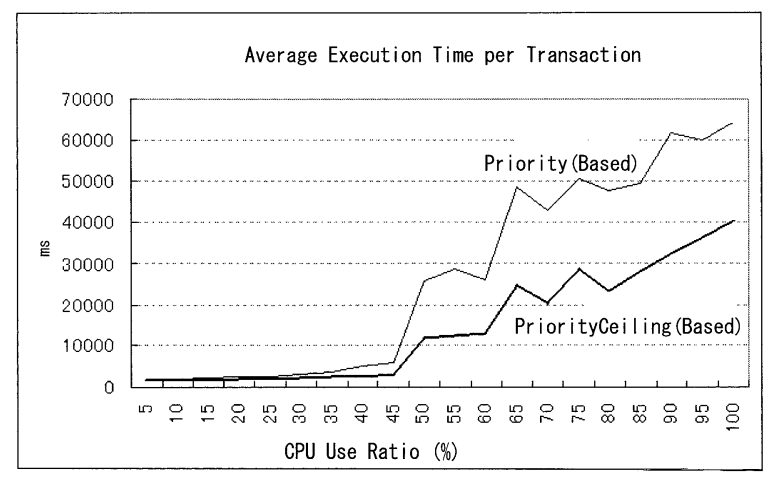

Fig. 16 Average execution time per transaction vs CPU use ratio for test2

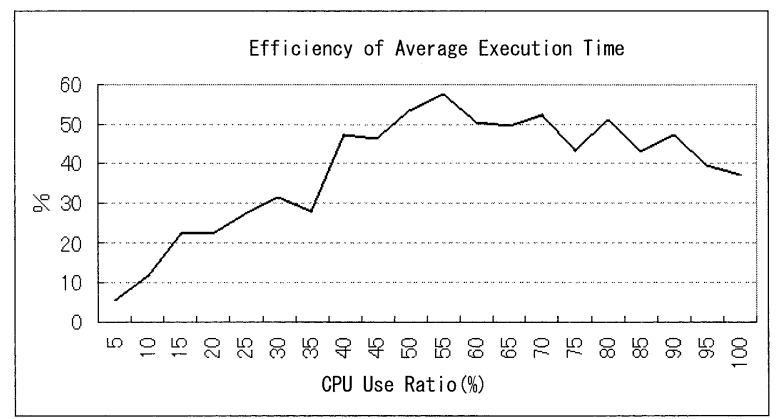

Fig. 17 Efficiency of average execution time per transaction vs CPU use ratio for test 2

状態になるのが早い分, 実行候補として選ばれるのは遅 くなるという状況は，使用率 $40 \%$ 以降のゾーンでは必ず しも成立しない。そこで, 使用率と一時停止時間・待ち 時間の関係を異なる視点から見ることにする。両手法に おける，サブトランザクションの実行時間に対する一時 停止時間と待ち時間の占める割合を Fig.19に表した。

まず，待ち時間を比較すると，プライオリティシーリ ング手法が安定しているのに対して, 従来手法は使用率 に関わらず不安定である。この原因は，積み残しの発生 が原因であると考えられ，4.3.3で述べた通りに実証さ れた。つぎに，一時停止時間を比較する。使用率が上が るとともに一時停止時間が長くなることは容易に予想で きた．さらに詳しく見ると，使用率 $35 \%$ 付近から，従 来手法よりプライオリティシーリング手法の方が割合が 低くなっている。ここで, Fig.17の実行時間の効率性と 比較すると, 一時停止時間の割合が従来手法より大きく 下回るゾーンと, 実行時間の効率が高くなるゾーンが重 なっている。これにより，一時停止時間が実行時間の効 率性に大きく影響していることが分かる，さらに，従来 手法の一時停止時間の割合が不安定であるのに対して, プライオリティシーリング手法は安定している.とくに 使用率が高くなった 50 \% 付近からは非常に安定する。一 時停止時間が実行時間の効率性に結びつくことを考慮す ると, 使用率が上がるとともに, 実行時間も安定すると いうことがいえる。つまり，使用率が高いほど，プライ 


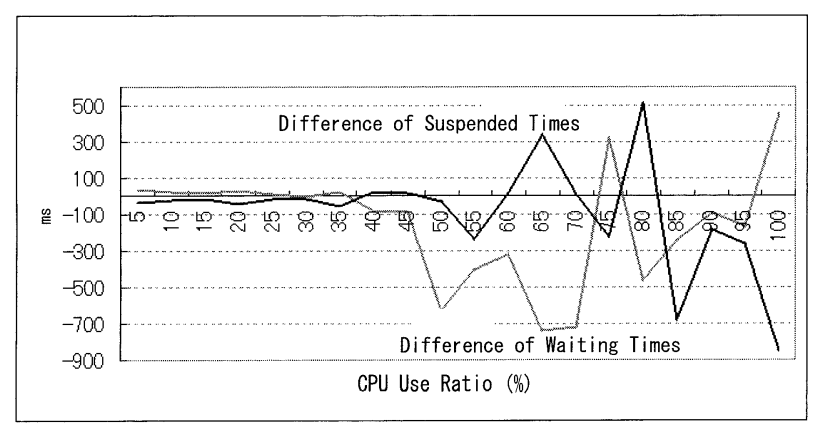

Fig. 18 Difference between average suspended time and average waiting time vs CPU use ratio for test2

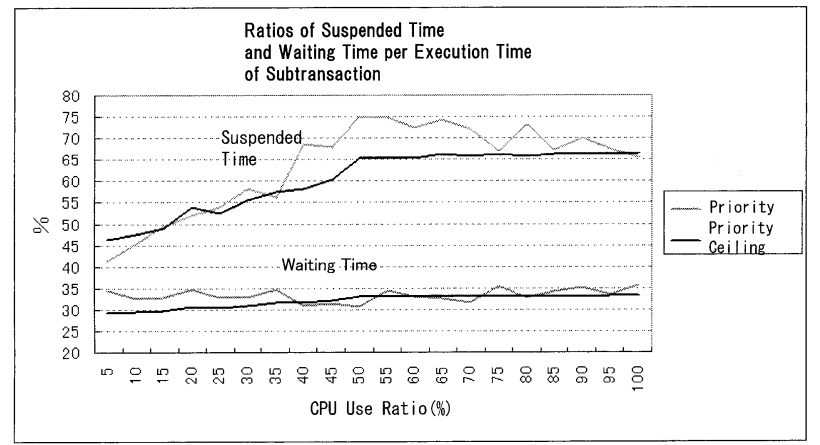

Fig. 19 Ratios of suspended time and waiting time per execution time of subtransaction

オリティシーリング手法の従来手法に対する優位性を示 している.

性能評価を要約すると，プライオリティシーリングに よるオブジェクト指向トランザクション処理は, 従来手 法が抱えていたサブトランザクションの積み残しを解消 するとともに，その結果，従来手法に比べて，実行時間 が短いことが実証された，さらに，互換の組合せが多い 状況において，従来手法は実行時間が不安定であるのに 対して，プライオリティシーリング手法が安定した結果 を得ることにより，互換時におけるプライオリティシー リング手法の有効性が明らかにされた。また，使用率テ ストにおいて，一時停止時間が実行時間の効率性に大き く影響することを確かめられた。さらに，使用率が高く ても，プライオリティシーリング手法は安定かつ優れた 効率性を提供することが実証された。

\section{5. おわりに}

本論文は，プライオリティシーリングをオブジェクト 指向卜ランザクション処理に適用し, 新たなトランザク ションスケジューリングを提案することにより，意味的 並行処理制御における問題点である積み残し問題を解 決した。論文の前半では，オブジェクト指向トランザク ションのアルゴリズムを提案し，オブジェクト指向直列 可能性を満たすことを示した，また，後半では，提案し たアルゴリズムの性能評価をおこなった。性能評価では， write 率および使用率を変化させることにより，様々な
視点から実験をおこなった. write率テストにおいて，積 み残しがwrite率に影響されることを実証した上で，提 案したプライオリティシーリング手法が積み残し問題を 解決し, トランザクション処理の安定性および効率性を 保証することを示した。使用率テストにおいて，使用率 が増加した場合にも高い性能評価が得られることを示 した。このような性能評価を通して，提案手法であるプ ライオリティシーリングによるオブジェクト指向トラン ザクション処理の有効性を実証することができた．最後 に，本論文における提案手法が有効となる使用目的につ いて触れる。互換のみの組合せが多い状況においても， 実行時間の安定性および効率性の視点から提案手法の有 効性が性能評価で確認された。しかし, 先着トランザク ションにおけるサブトランザクションの積み残しの解消 よりも，後着トランザクションのサブトランザクション の read 命令を一刻も早く実行することが目的にかなう 場合もありえる。このような異なる目的に対して, 提案 手法が必ずしも満足のいく解を与える保証はないが，今 後の研究課題としたい.

\section{参 考 文 献}

[1] T. C. Rakow, J. Gu and E. J. Neuhold: Serializability in object-oriented database system; Proc. IEEE 6th International Conference on Data Engineering, pp. 112-120 (1990)

[2] P. Muth, T. C. Rakow, G. Weikum, P. Brössler and C. Hasse: Semantic concurrency control in objectoriented database systems; Proc. IEEE 9th International Conference on Data Engineering, pp. 23-32 (1993)

[3] L. Sha, R. Rajkumar and J. P. Lehoczky: Priority inheritance protocols: An approach to real-time synchronization; IEEE Transaction on Computer, Vol. 38, No. 9, pp. 1175-1185 (1990)

[4] O. Ullusoy and G. G. Belford: Real-time transaction scheduling in database systems; Information Systems, Vol. 18, No. 8, pp. 559-580 (1993)

[5] Y. Murakami, M. Nishikaku, T. Okada, M. Sakaguchi and M. Nagata: Real-time scheduling for semantic concurrency control of object-oriented database systems; Proc. Seventh International Workshop on Database and Expert Systems Applications (DEXA96), pp. 214-221 (1996)

[6] K. Asai, J. Nishibayashi, K. Yoshihara and M. Nagata: Object-oriented serializability in real-time concurrency control; Proc. Cooperative Database Systems for Advanced Applications (CODAS96), pp. 4851 (1996)

[7] K. Asai, J. Nishibayashi, K. Yoshihara and M. Nagata: Priority-ceiling based concurrency control of object-oriented database; Proc. IASTED International Conference on Artifitial Intelligence and Soft Computing, pp. 254-260 (1998) 
[8] K. Asai, H. Komura and M. Nagata: Performance evaluation of priority ceiling based transaction scheduling in object-oriented database; Proc. International Conference on Computer Processing of Oriental Language (ICCPOL), pp. 277-280 (1999)

[9] P. Bernstein and E. Newcomer: Priciples of Transaction Processing, Morgan Kaufmann (1997)

[10] A. K. Elmagarmid (Ed.): Database Transaction Models for Advanced Applications, Morgan Kaufmann (1991)

[11] J. Gray (Ed.): The Benchmark Handbook, Morgan Kaufmann (1993) 